\title{
Cytological and reproductive aspects in the Caespitosa group of Paspalum
}

\author{
Aspectos citológicos e reprodutivos no grupo Caespitosa do gênero Paspalum
}

\author{
Marisa Toniolo Pozzobon ${ }^{\mathrm{I}^{*}}$ Marcelo Broilo Paganella ${ }^{\mathrm{II}}$ Sileuza dos Santos ${ }^{\mathrm{I}}$ \\ José Francisco Montenegro Valls ${ }^{\mathrm{I}}$
}

\begin{abstract}
Somatic chromosome numbers are reported for thirty four germplasm accessions of Paspalum, Caespitosa group, representing five different species. All five species have shown $x=10$ as the basic chromosome number. The diploid $2 n=20$ chromosome number was confirmed for $\boldsymbol{P}$. chacoense and $\boldsymbol{P}$. indecorum, as well as sexuality for the latter. This is the first report of the chromosome number and cytological behavior for P. ligulare $(2 n=20$ and 40), $\boldsymbol{P}$. pleostachyum $(2 n=20,30$ and 40$)$ and $\boldsymbol{P}$. redondense $(2 n=20$ and 40). The present results document regular meiosis in diploid accessions, with primarily bivalent pairing at diakinesis and metaphase I. Polyploids of these species had irregular meiosis, with univalent, trivalent, and quadrivalent chromosome associations. Diploid accessions of $\boldsymbol{P}$. pleostachyum and $\boldsymbol{P}$. ligulare have shown a single meiotic embryo-sac, indicating sexual reproduction, while the triploid and one of the tetraploid accessions of P. pleostachyum have shown aposporic embryo-sacs of nucelar origin, and a few meiotic sacs, suggesting facultative apomixis. Identification of the new diploid accessions may prove useful for phylogenetic studies of Paspalum, as well as for breeding programs focusing on the forage potential of species of the Caespitosa group.
\end{abstract}

Key words: mode of reproduction, ploidy level.

\section{RESUMO}

Números cromossômicos são reportados para trinta e quatro acessos, representando cinco espécies de Paspalum, grupo Caespitosa. Todos são múltiplos do número básico $x=10$. Confirmou-se o número diploide $2 n=20$ para $\boldsymbol{P}$. chacoense e $\boldsymbol{P}$. indecorum como, também, a sexualidade para $\boldsymbol{P}$. indecorum. As contagens cromossômicas são inéditas para $\boldsymbol{P}$. ligulare $(2 n=20$ e 40), P. pleostachyum $(2 n=20,30$ e 40) e P. redondense $(2 n=20$ e 40). A meiose foi regular nos diploides, com pareamento em bivalentes na diacinese e metáfase I, enquanto irregularidades, tais como univalentes, trivalentes e quadrivalentes, foram comuns nos poliploides. Acessos diploides de $\boldsymbol{P}$. pleostachyum e $\boldsymbol{P}$.

\begin{abstract}
ligulare mostraram um único saco embrionário meiótico em cada óvulo, indicando reprodução sexual. O acesso triploide e um dos tetraploides de P. pleostachyum evidenciaram sacos apospóricos e alguns sacos meióticos, sugerindo apomixia facultativa. A identificação dos novos acessos diploides poderá se mostrar bastante útil para o estudo filogenético do gênero, assim como para programas de melhoramento genético focados no potencial forrageiro das espécies do grupo Caespitosa.
\end{abstract}

Palavras-chave: modo de reprodução, nível de ploidia.

\section{INTRODUCTION}

In the informal taxonomic framework proposed by CHASE (1929) for the genus Paspalum L., the Caespitosa group encompasses rock-dwelling and calcicole species, and is outstanding for their ability to cope with extreme climatic stresses, such as alternated drought and flooding, in their natural areas of occurrence. Five perennial Brazilian species, $\boldsymbol{P}$. chacoense Parodi, $\boldsymbol{P}$. indecorum Mez, P. ligulare Nees, $\boldsymbol{P}$. pleostachyum Döll, and $\boldsymbol{P}$. redondense Swallen, are gathered in this group.

There are strong morphological similarities between these species and, at the base of their tufts, they resemble distinct forms of Paspalum notatum Flüggé (VALLS \& POZZOBON, 1987). Accordingly, the species with the southernmost occurrence, $\boldsymbol{P}$. indecorum, has been included in the Notata group by FERNANDES et al. (1974), without further explanation. However, more recent reviews of this

\footnotetext{
IEmbrapa Recursos Genéticos e Biotecnologia (CENARGEN), Brasília, DF, Brasil. E-mail: marisa.pozzobon@embrapa.br. *Autor para correspondência.

IUniversidade de Brasília (UnB), Brasília, DF, Brasil. 
informal group (CANTO-DOROW et al., 1996; ZULOAGA et al., 2004; ESSI \& SOUZA-CHIES, 2007) do not include it in Notata, in spite of the presence of $\boldsymbol{P}$. indecorum in the regional floras involved. It is noteworthy that I.L. BARRETO, one of the co-authors of the FERNANDES et al. (1974) paper, filed $\boldsymbol{P}$. indecorum as a member of the group Caespitosa in a subsequent publication (BARRETO, 1974).

The ranges of Caespitosa species are somewhat peculiar. Paspalum indecorum occurs in southeastern Paraguay, Northeastern Argentina, Southern Brazil, and Uruguay (QUARÍN \& BURSON, 1983). In Brazil, its occurrence is concentrated in the western portion of Rio Grande do Sul State, extending along the border with Santa Catarina State, established by the Uruguay river, where it grows on the surface of river rocks, rooting in crevices.

Paspalum redondense is endemic to Brazil and restricted to shallow rocky soils in the southern portion of Paraná State. Paspalum chacoense is typical of the semi-arid Chaco region of northern Argentina and northwestern Paraguay (BURSON, 1985), penetrating Brazil in the southwestern portion of Mato Grosso do Sul State, always close to the border line (VALLS, 1987), in the municipality of Porto Murtinho. A northernmost site of occurrence in the municipality of Corumbá, less than $30 \mathrm{~km}$ to the Brazilian border with Bolivia, suggests its presence also in the latter country.

Paspalum pleostachyum occurs in Brazil and in the West Indies. In Brazil, it is frequent in the Northeast Region, both in the interior and along the Atlantic Coast, where it reaches the Marajó Island, at the mouth of the Amazon river. Paspalum ligulare is registered to Mexico, Central America, Venezuela and Brazil, where it also occurs in the Northeast. The last two species may grow sympatrically (VALLS \& POZZOBON, 1987) and may form dense communities in alluvial, eventually salt affected soils.

Paspalum indecorum is a usually glabrous cespitose summer grass, with thick, short and strong rhizomes. It flowers from October to March, shows a low stature (near $40 \mathrm{~cm}$ high), and is considered a good forage plant. It grows in low, humid grasslands, with acidic, sandy or loam soils, in areas subject to floods, but also on flat tops of rock outcrops in grassland areas. Although vegetatively similar to $\boldsymbol{P}$. notatum, it shows much smaller, quite different spikelets, and is locally known as "grama do Sarandi" (PARODI, 1937; ROSENGURTT et al., 1970; ARAÚJO, 1971).

Paspalum chacoense is glabrous, $50-75 \mathrm{~cm}$ high, with short and vigorous rhizomes (PARODI,
1932). It may be of great interest, as it tolerates quite dry places. CHASE (1929) considered it to belong in the Setacea group, but its affinity to other species in the Caespitosa group is quite obvious. Paspalum ligulare and $\boldsymbol{P}$. pleostachyum usually produce higher, denser tussoks, either as isolated plants or in dense colonies, with visible differences in plant height and leaf blade dimensions between individual tufts.

Little is known on the cytology and mode of reproduction of this group of species. Previous information has been published for Paspalum chacoense and $\boldsymbol{P}$. indecorum only (FERNANDES et al., 1974; QUARÍN, 1977; QUARÍN \& BURSON, 1983; BURSON, 1985; PAGLIARINI et al., 2001; HOJSGAARD et al., 2009). Basic chromosome number of these two sexual, diploid, $2 n=20$ species is $x=10$. However, the widespread presence of distinct chromosome races in a same species, as well as the occurrence of apomitic reproduction linked to polyploidy is a reality in Paspalum. So, the present investigation has been conducted to determine the chromosome number of a series of Brazilian accessions of Caespitosa, and to analyze the type of embryo sac in representatives of three species.

Knowledge on the method of reproduction is a mandatory item in any program of genetic improvement of wild grasses for forage purposes. This information may be useful to develop strategies for germplasm conservation and towards understanding the taxonomic relationships among species of the Caespitosa group.

\section{MATERIAL AND METHODS}

Germplasm accessions from several collection sites in Brazil (Table 1) were maintained in a greenhouse at Embrapa Genetic Resources and Biotechnology, in Brasília, Federal District, for sampling. Voucher herbarium specimens are deposited at the herbarium of Embrapa Genetic Resources and Biotechnology (acronym CEN).

Somatic chromosome numbers were obtained from root-tip cells without fixation, pretreated in a 1-bromonaphtalene saturated solution, hydrolyzed in $\mathrm{Normal} \mathrm{HCl}$ at $60^{\circ} \mathrm{C}$, and stained with Schiff reagent. Propionic carmine $1 \%$ was used during smearing. At least five cells, but usually over ten with good spreading and no chromosome overlapping, were analyzed for each individual plant.

Meiotic analysis provided the chromosome number and observation of the chromosome pairing and segregation behavior for accessions of $P$. ligulare, $P$. pleostachyum and $P$. redondense. 
Table 1 - Paspalum species, collector number, chromosome number, and origin of accessions analyzed.

\begin{tabular}{|c|c|c|c|}
\hline Species & Collector number & $2 n$ & State and municipality of collection \\
\hline \multirow{2}{*}{ P. chacoense } & V 8593 & 20 & MS, Porto Murtinho \\
\hline & V 9083 & 20 & MS, Corumbá \\
\hline \multirow{15}{*}{ P. indecorum } & Bd 219 & 20 & RS, Santo Antônio das Missões \\
\hline & Bd 289 & 20 & RS, Quaraí \\
\hline & V 5851 & 20 & RS, Porto Lucena \\
\hline & V 7319 & 20 & RS, Santo Antônio das Missões \\
\hline & V 9634 & 20 & RS, Santana do Livramento \\
\hline & V 9660 & 20 & RS, Quaraí \\
\hline & V 9808 & 20 & RS, São Borja \\
\hline & V 10649 & 20 & RS, São Luiz Gonzaga \\
\hline & V 12380 & 20 & RS, Quaraí \\
\hline & V 12381 & 20 & RS, Quaraí \\
\hline & V 12422 & 20 & RS, São Luiz Gonzaga \\
\hline & V 12423 & 20 & RS, São Luiz Gonzaga \\
\hline & V 12783 & 20 & RS, Santana do Livramento \\
\hline & V 12787 & 20 & RS, Santana do Livramento \\
\hline & V 12788 & 20 & RS, Santana do Livramento \\
\hline \multirow{4}{*}{ P. ligulare } & V 6198 & $20 *$ & PE, Santa Maria da Boa Vista \\
\hline & V 10882 & $20 *$ & BA, Jacobina \\
\hline & V 10943 & $40 *$ & PB, Sousa \\
\hline & V 13083 & 40 & MG, Monte Azul \\
\hline \multirow{11}{*}{ P. pleostachyum } & Sc 70 & $20 * *$ & PE, Fernando de Noronha \\
\hline & CPATU 1173 & $20 * *$ & PA, Ilha de Marajó \\
\hline & CPATU 1176 & $20 *$ & PA, Ilha de Marajó \\
\hline & CPATU 1177 & 20 & PA, Ilha de Marajó \\
\hline & CPATU 1178 & $20 * *$ & PA, Ilha de Marajó \\
\hline & V 10986 & $20 *$ & CE, Aracati \\
\hline & V 10935 & $30 * *$ & CE, Milagres \\
\hline & V 10880 & $40 * *$ & BA, Morro do Chapéu \\
\hline & V 10881 & $40^{*}$ & BA, Jacobina \\
\hline & V 10973 & $40 * *$ & RN, Currais Novos \\
\hline & V 13119 & 40 & RN, Tibau do Sul \\
\hline \multirow{10}{*}{ P. redondense } & V 11370-j & $20 *$ & PR, Guarapuava \\
\hline & V 11370-v & $20 *$ & PR, Guarapuava \\
\hline & V 11370-y & 20 & PR, Guarapuava \\
\hline & V 11370-z & 20 & PR, Guarapuava \\
\hline & V 11370-e & $40^{*}$ & PR, Guarapuava \\
\hline & V 11370-h & 40 & PR, Guarapuava \\
\hline & V 11370-i & 40 & PR, Guarapuava \\
\hline & V 11370-m & 40 & PR, Guarapuava \\
\hline & V 11370-q & 40 & PR, Guarapuava \\
\hline & V 11371 & $20 * *$ & PR, Guarapuava \\
\hline
\end{tabular}

Bd=I.I.Boldrini; Sc=A.O.Scariot; V=J.F.M.Valls and collaborators, CPATU=numbers at Embrapa Amazônia Oriental Forage Plant Genebank. States: BA=Bahia; $\mathrm{CE}=\mathrm{Ceará;} \mathrm{MG}=$ Minas Gerais; MS=Mato Grosso do Sul; PA=Pará; PB=Paraíba; PE=Pernambuco; PR=Paraná, RN=Rio Grande do Norte; RS= Rio Grande do Sul.

*Meiotic counts only; **Mitotic and meiotic counts.

Ciência Rural, v.43, n.11, nov, 2013. 
Young inflorescences were fixed in ethanol: glacial acetic acid (3:1) for $24 \mathrm{~h}$ at room temperature, and stored in $70 \%$ ethanol at $4^{\circ} \mathrm{C}$ until used for analysis. Microsporocyte slides were prepared by maceration and stained with $1 \%$ propionic carmine. The number of cells analyzed per plant ranged according to the availability of inflorescences collected in each plant.

Embryological analyses were conducted in order to study the mode of reproduction of some plants with distinct ploidy levels. Spikelets at anthesis were fixed overnight in FAA (70\% ethanol:glacial acetic acid:folmaldehyde/90:5:5). Ovaries were dissected, cleared with Herr's technique (1971) and observed using differential interferential contrast microscopy.

\section{RESULTS AND DISCUSSION}

Thirty four accessions representing Paspalum chacoense, P. indecorum, P. ligulare, $\boldsymbol{P}$. pleostachyum and $\boldsymbol{P}$. redondense had their chromosome numbers determined (Table 1). Table 2 lists the accessions checked for meiotic behavior, and mode of reproduction.

The Brazilian accessions of Paspalum chacoense and $\boldsymbol{P}$. indecorum are diploid, with
$2 \mathrm{n}=2 \mathrm{x}=20$ chromosomes, in agreement with previously published reports (FERNANDES et al., 1974; QUARÍN, 1977; QUARÍN \& BURSON, 1983; BURSON, 1985; PAGLIARINI et al., 2001; HOJSGAARD et al., 2009). Both species reproduce sexually (BURSON, 1985; QUARÍN \& BURSON, 1983). In this paper sexuality was confirmed for one accession of $\boldsymbol{P}$. indecorum. According to QUARÍN (pers. commun.), this species is considered autoincompatible.

Chromosome numbers for $\boldsymbol{P}$. ligulare, $\boldsymbol{P}$. pleostachyum and $\boldsymbol{P}$. redondense are here documented for the first time. For all three species, diploid cytotypes with $2 n=2 x=20$ and tetraploids with $2 n=4 x=40$ were found. The most variable of the five species, $\boldsymbol{P}$. pleostachyum, also showed a triploid cytotype with $2 n=3 x=30$ chromosomes. The occurrence of distinct ploidy levels in a single species is a common event in the genus Paspalum (QUARÍN, 1992). Many species show diploid, sexual cytotypes, which are alogamous due to self-sterility, and, apomitic tetraploid cytotypes, usually pseudogamous and self-fertile. Thus, wide cytological screening is a pre-requisite in Paspalum breeding programs (PAGLIARINI et al. 2001; QUARÍN, 1992).

Table 2 - Meiotic chromosome configurations at diakinesis and metaphase I and mode of reproduction of Paspalum.

\begin{tabular}{|c|c|c|c|c|c|c|c|}
\hline \multirow{2}{*}{$\begin{array}{l}\text { Species/ } \\
\text { Collector number }\end{array}$} & \multirow{2}{*}{$2 n$} & \multirow{2}{*}{ N. PMCs* } & \multicolumn{4}{|c|}{------------------- Average/CMP (Range in parenthesis) ---------------- } & \multirow{2}{*}{$\begin{array}{c}\text { Reproduction } \\
\left.\text { ( } \mathrm{N}^{\mathrm{o}} \text { ovules }\right)\end{array}$} \\
\hline & & & I & II & III & IV & \\
\hline \multicolumn{8}{|l|}{ P. indecorum } \\
\hline V 5851 & 20 & - & - & - & - & - & Sexual (32) \\
\hline \multicolumn{8}{|l|}{ P. ligulare } \\
\hline V 6198 & 20 & 45 & - & 10.00 & - & - & Sexual (22) \\
\hline V 10882 & 20 & 15 & - & 10.00 & - & - & - \\
\hline V 10943 & 40 & 29 & $0.14(0-3)$ & $15.48(10-18)$ & $0.07(0-1)$ & $2.17(1-5)$ & - \\
\hline \multicolumn{8}{|l|}{ P. pleostachyum } \\
\hline Sc 70 & 20 & 75 & - & 10.00 & - & - & Sexual (59) \\
\hline CPATU 1173 & 20 & 35 & - & 10.00 & - & - & - \\
\hline CPATU 1177 & 20 & - & - & - & - & - & Sexual (63) \\
\hline CPATU 1178 & 20 & 97 & - & 10.00 & - & - & - \\
\hline V 10986 & 20 & 36 & - & 10.00 & - & - & - \\
\hline V 10935 & 30 & 26 & $5.50(1-8)$ & $8.23(4-13)$ & $1.96(0-5)$ & $0.54(0-2)$ & Apomixis (20) \\
\hline V 10880 & 40 & 6 & $1.33(0-2)$ & $13.76(10-18)$ & $0.67(0-2)$ & $2.33(1-4)$ & Apomixis (20) \\
\hline V 10881 & 40 & 30 & $2.07(0-8)$ & $13.93(9-18)$ & $0.07(0-2)$ & $2.47(1-5)$ & - \\
\hline V 10973 & 40 & 6 & $1.33(0-4)$ & $16.00(13-18)$ & - & $1.67(1-3)$ & - \\
\hline \multicolumn{8}{|l|}{ P. redondense } \\
\hline V 11370-j & 20 & 92 & - & 10.00 & - & - & - \\
\hline V 11370-v & 20 & 25 & - & 10.00 & - & - & - \\
\hline V 11370-e & 40 & 59 & $1.03(0-4)$ & 12.97 (6-18) & $0.08(0-2)$ & $3.15(0-7)$ & - \\
\hline
\end{tabular}

Collectors numbers and institutional denominations: Sc=A.O.Scariot; V=J.F.M.Valls and collaborators. CPATU=Local identification numbers at Embrapa Amazônia Oriental Forage Plant Genebank. *PMCs = pollen mother cells. 
Analysis of meiotic behavior at diploid level showed pairing as bivalents (10 II) (Figure $1 \mathrm{~A}-\mathrm{C})$ and regular chromosome segregation during both meiotic divisions. Tetraploids and the triploid accession (Figure 1D-E) showed chromosomes associating predominantly as bivalents, but a low frequency of uni- and trivalents, and tetravalents could be observed. Even if in reduced frequencies, meiotic abnormalities were found, such as non-orientation of chromosomes at metaphase I, irregular disjunction and stickiness at anaphase I, laggards, bridges and/or fragments at anaphase and telophase I. Such precocious chromosome migration to the poles during metaphases, and anaphase laggards result in micronuclei at telophase. However, meiotic behavior varied among polyploid accessions. Unbalanced gametes probably generated from these irregularities could compromise pollen fertility (PAGLIARINI et al., 2001).

Two diploid accessions of $\boldsymbol{P}$. pleostachyum, one of $\boldsymbol{P}$. ligulare and one of $\boldsymbol{P}$. indecorum showed a single and typical embryo sac per ovule, suggesting sexual reproduction, while the rare triploid and one of the tetraploid accessions of $\boldsymbol{P}$. pleostachyum showed aposporic sacs of nucelar origin and some meiotic sacs, suggesting facultative apomixis. These findings demonstrate the cytological and reproductive diversity within this group.

A polyploidisation model applicable to several species of Paspalum (QUARÍN, 1992) comprises co-specific sexual diploids, rare apomictic triploids, and apomictic tetraploids which usually constitute the most common cytotype for the species. Triploids seem to be rare individuals which arise in a diploid population, probably through unreduced gametes $(2 n+n)$ or in mixed $2 x-4 x$ populations, where there are two possible origins: by unreduced gametes as in diploid populations, or by $2 \mathrm{x} \cdot 4 \mathrm{x}$ crosses (NORRMANN et al., 1994). Unreduced egg-cells may be functional and, when fertilized by a reduced male gamete, they give rise to triploid plants $(2 x+x=3 x)$. These triploids may, in turn, be the origin of new tetraploids $(3 \mathrm{x}+\mathrm{x}=4 \mathrm{x})$ (SIENA et al., 2008). Otherwise, the $2 n$ gamete of an additional aposporous sac can be fertilized by a male haploid gamete from a neighbouring apomictic 4x plant (2n) to establish a new apomictic $4 \mathrm{x}$ genotype, as was achieved experimentally in $\boldsymbol{P}$. rufum (NORRMANN et al., 1994).

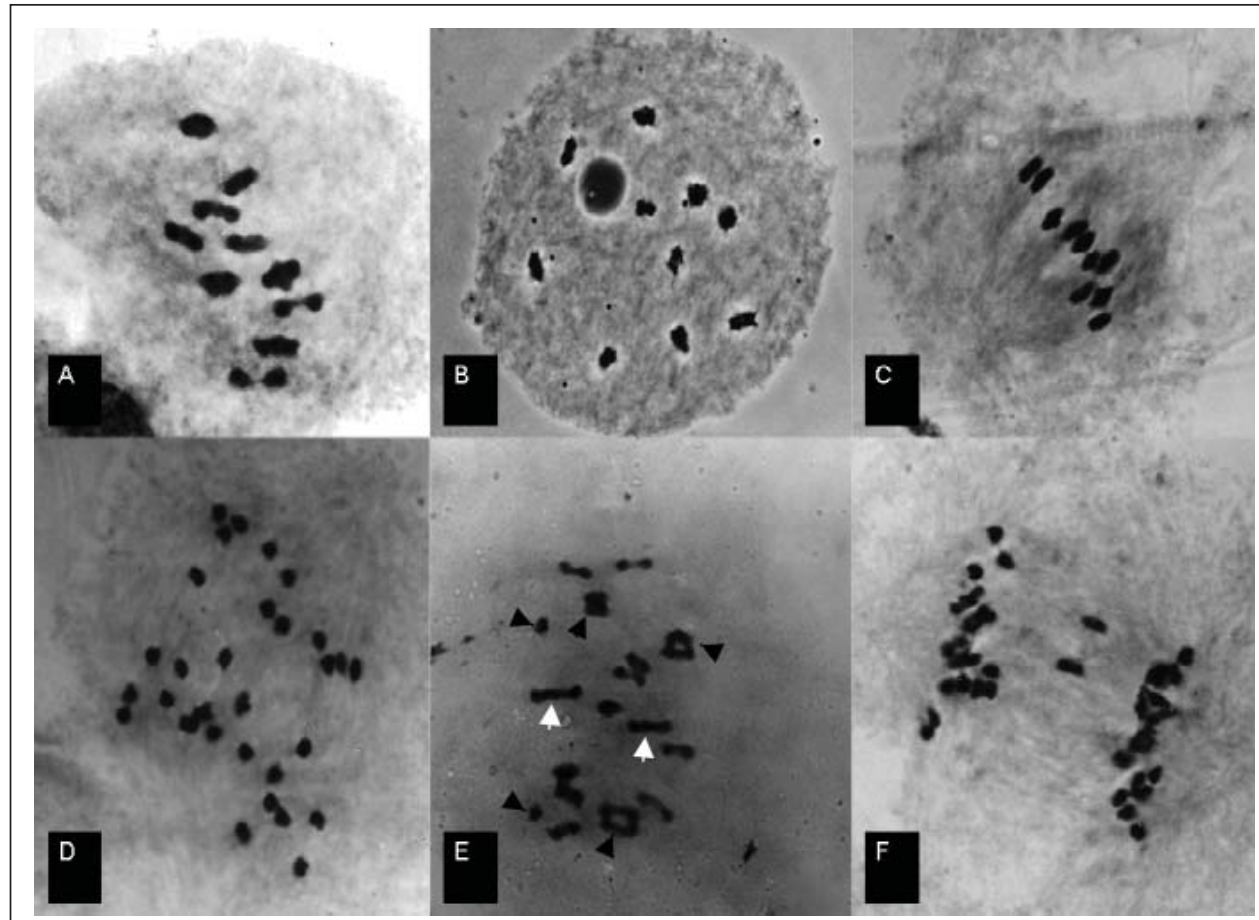

Figure 1 - (A-F) Meiotic behavior in pollen mother cells: (A) metaphase I in Paspalum ligulare with 10 bivalents; (B) diakinesis in $\boldsymbol{P}$. redondense with 10 bivalents; (C) metaphase I in $\boldsymbol{P}$. pleostachyum with 10 bivalents; (D) anaphase I in triploid $\boldsymbol{P}$. pleostachyum with 12+18 chromosome distribution; (E) metaphase I in tetraploid P. pleostachyum with 2 univalents (arrowheads), 10 bivalents, 2 trivalents (white arrow) and 3 quadrivalents (black arrow) associations; (F) anaphase I with laggards chromosomes in tetraploid $\boldsymbol{P}$. pleostachyum. 
Based on the present results, the species analyzed of the Caespitosa group of Paspalum may be characterized by (1) the predominance of sexuality (and the inferred allogamy) in all five species, (2) the presence of two ploidy levels (diploid and tetraploid) in $\boldsymbol{P}$. ligulare and $\boldsymbol{P}$. redondense, (3) the occurrence of three ploidy levels (diploid, triploid and tetraploid) in $\boldsymbol{P}$. pleostachyum, and (4) apomixis linked to polyploidy. (2), (3) and (4) suggest the model above.

There is an apparent association between ploidy level and altitude of the collection sites of $\boldsymbol{P}$. pleostachyum, as all five diploid accessions were obtained near the sea level. Except for the site of the tetraploid accession V 13119, also collected almost at sea level, collection sites of the triploid and the remaining tetraploid accessions of $\boldsymbol{P}$. pleostachyum thrive between 350 and 450 meters above the sea level, but reach the extreme elevation of 1020 meters at Morro do Chapéu, in Bahia State (accession V 10880). A similar association was reported earlier for P. compressifolium Swallen (QUARÍN et al. 1996), and $\boldsymbol{P}$. glaucescens Hack. (POZZOBON \& VALLS, 2000), where polyploidy associated to apomixis was interpreted as selectively advantageous for harsher environments in the subtropical Southern Brazilian highlands. A corresponding situation could probably favor the spread and survival of apomitic tetraploids, producers of genetically uniform progenies, where harsh conditions are determined by the frequent and severe dry periods in the higher elevations of the Brazilian semiarid Northeast.

Ongoing morphological investigation is growingly supporting the possibility of conspecificity of $\boldsymbol{P}$. pleostachyum and $\boldsymbol{P}$. ligulare. In such case, the present cytological results from accessions originally filed under $\boldsymbol{P}$. ligulare, including diploids from elevations near 450 meters above sea level, in Santa Maria da Boa Vista, Pernambuco State, and Jacobina, Bahia State, would conspire against a direct association between elevation and ploidy level. Morphological variation shown by the accessions here collated of $\boldsymbol{P}$. ligulare/P. pleostachyum would still be much less evident than the morphological variation recognized between tetraploid accessions of a well studied species with diploid, triploid, tetraploid, and even pentaploid cytotypes, such as P. notatum (GATES et al., 2004), where continuing variation historically gave rise to the description of several taxa, all presently merged in the reasonably well accepted synonymy of $\boldsymbol{P}$. notatum. Likewise, $\boldsymbol{P}$. pleostachyum gathers three synonyms (CHASE, 1929).
Results of the present research stress the need for continuing cytogenetic characterization of native forage grasses. In line with additional papers that cover a broader sampling, both in terms of accessions and geographical sites of origin of available Paspalum germplasm (HONFI et al., 1990; POZZOBON et al., 2000; MORRONE et al., 2006; HOJSGAARD et al., 2009), they document the finding of more than a single ploidy level in distinctive accessions of same species.

Despite identifying promising accessions, the Paspalum breeding program in effect depends on sexual accessions to act as female genitors in hybridizations. The predominance of diploid accessions here described brings new possibilities as concerns the use of such plants in future breeding programs, following approaches as those utilized for $\boldsymbol{P}$. notatum (FORBES \& BURTON, 1961). Also, it is important for phylogenetic analyses, once it allows for the incorporation in such studies of diploid accessions of Caespitosa species other than $\boldsymbol{P}$. chacoense and $\boldsymbol{P}$. indecorum, both already included in a previous research (QUARÍN \& BURSON, 1983; BURSON, 1985).

Perspectives of use are particularly favorable for $\boldsymbol{P}$. redondense, once this species has desirable agronomic characteristics, its growth habit is similar to that of $\boldsymbol{P}$. notatum, and its leaves are quite tender, suggesting a high potential of use in cultivated pastures. The tetraploid level was so far unknown in this species, and its presence suggests the existence of apomitic lines, of great interest to the seed market, however, not evaluated in the present research. The frequent self-incompatibility of diploid, sexual plants, usually compromising seed production, is usually seen as a problem by the forage seed industry, which can be overcome by apomixis.

Complementary studies aiming to determine the mode of reproduction, and seed production under self- and cross-pollination will be additionally conducted, and new accessions are likely to be available for characterization with continuing germplasm collecting. Thus, wide cytological screening remains a pre-requisite in Paspalum breeding programs.

\section{ACKNOWLEDGMENT}

José Francisco Montenegro Valls has a fellowship from Conselho Nacional de Desenvolvimento Científico e Tecnológico (CNPq).

Ciência Rural, v.43, n.11, nov, 2013. 


\section{REFERENCES}

ARAÚJO, A.A. Principais gramíneas do Rio Grande do Sul. 3.ed. Porto Alegre: Sulina, 1971. 255p.

BARRETO, I.L. O gênero Paspalum (Gramineae) no Rio Grande do Sul. 1974. 258f. Tese (Livre Docência) - Universidade Federal do Rio Grande do Sul, Porto Alegre, RS.

BURSON, B.L. Cytology of Paspalum chacoense and $\boldsymbol{P}$. durifolium and their relationship to $\boldsymbol{P}$. dilatatum. Botanical Gazette, v.146, p.124-129, 1985.

CANTO-DOROW, T.S. et al. Revisão taxonômica das espécies de Paspalum grupo Notata (Poaceae - Paniceae) do Rio Grande do Sul, Brasil. Iheringia, v.47, p.3-44, 1996.

CHASE, A. The North American species of Paspalum. Contributions from the United States National Herbarium, v.28, p.1-310, XI-XVII, 1929.

ESSI, L.; SOUZA-CHIES, T.T. Phylogeny of Linearia and Notata groups of Paspalum L. (Poaceae, Panicoideae, Paniceae) and related species. Genetic Resources and Crop Evolution, v.54, p.779-791, 2007. Available from: <http://link.springer.com/article /10.1007\%2Fs10722-006-9148-7>. Accessed: dec. 12, 2012. doi: $10.1007 / \mathrm{s} 10722-006-9148-7$.

FERNANDES, M.I.B.M. et al. Cytological and evolutionary relationships in Brazilian forms of Paspalum (Gramineae). Caryologia, v.27, p.455-464, 1974.

FORBES, I., Jr.; BURTON, G.W. Cytology of diploids, natural and induced tetraploids, and intraspecific hybrids of bahiagrass, Paspalum notatum Flugge. Crop Science, v.1, p.402-406, 1961. Available from: <https://www.crops.org/publications/cs/tocs/1/6>. Accessed: dec. 12, 2012. doi: 10.2135/cropsci1961.0011183X000 100060006x.

GATES R.N. et al. Bahiagrass. In: MOSER, L.E. et al. (Eds.). Warm-season (C4) grasses. Madison: ASA, CSSA, and SSSA, 2004. p.651-680.

HERR, J.M., Jr. A new clearing-squash technique for the study of ovule development in angiosperms. American Journal of Botany, v.58, p.785-790, 1971.

HOJSGAARD, D. et al. Chromosome numbers and ploidy levels of Paspalum species from subtropical South America (Poaceae). Genetic Resources and Crop Evolution, v.56, p.533-545, 2009. Available from: <http://link.springer.com/ article/10.1007\%2Fs10722-008-9384-0\#page-1>. Accessed: dec. 12, 2012. doi: 10.1007/s10722-008-9384-0.

HONFI, A.I. et al. Estudios cariológicos en gramíneas sudamericanas. Darwiniana, v.30, p.87-94, 1990.

MORRONE, O. et al. Chromosome studies in American Panicoideae (Poaceae). Annals of the Missouri Botanical Garden, v.93, p.647-657, 2006. Available from: <http://www.bioone.org/ doi/full/10.3417/0026-6493\%282006\%2993\%5B647\%3ACSIAP P\%5D2.0.CO\%3B2>. Accessed: dec. 13, 2012. doi: http://dx.doi. org/10.3417/0026-6493(2006)93[647:CSIAPP]2.0.CO;2

NORRMANN, G.A. et al. Post-zigotic seed abortion in sexual diploid $\times$ apomictic tetraploid intraspecific Paspalum crosses. Australian Journal of Botany, v.42, p.449-456, 1994.
PAGLIARINI, M.S. et al. Cytogenetic characterization of Brazilian Paspalum accessions. Hereditas, v.135, p.27-34, 2001. Available from: <http://dx.doi.org/10.1111/j.1601-5223.2001.00027.x>. Accessed: dec. 13, 2012. doi: 10.1111/j.1601-5223.2001.00027.x.

PARODI, L.R. Algunas gramíneas argentinas nuevas o críticas. Physis, v.11, p.129-138, 1932.

PARODI, L.R. Contribución al estudio de las gramíneas del género Paspalum de la Flora Uruguaya. Revista del Museo de la Plata, v.1, p.211-250, 1937.

POZZOBON, M.T. et al. Contagens cromossômicas em espécies brasileiras de Paspalum L. (Gramineae). Acta Botanica Brasilica, v.14, p.151-162, 2000. Available from: <http:// www.scielo.br/scielo.php?script=sci_issuetoc $\&$ pid $=0102-$ 330620000002\&lng=pt\&nrm=iso>. Accessed: dec. 13, 2012. http://dx.doi.org/10.1590/S0102-33062000000200003.

POZZOBON, M.T.; VALLS, J.F.M. Cytogeography and variation of stomatal size of Paspalum glaucescens (Gramineae; Paniceae) in Southern Brazil. Euphytica, v.116, p.251-256, 2000. Available from: <http://link.springer.com/article/10.102 3\%2FA\%3A1004005230300>. Accessed: dec. 13, 2013. doi: 10.1023/A:1004005230300.

QUARÍN, C.L. Recuentos cromosómicos en gramíneas de Argentina subtropical. Hickenia, v.1, p.73-78, 1977.

QUARÍN, C.L. The nature of apomixis and its origin in Panicoid grasses. Apomixis Newsletter, v.5, p.8-15, 1992.

QUARÍN, C.L.; BURSON, B.L. Cytogenetic relations among Paspalum notatum var. saurae, $P$. pumilum, $P$. indecorum and $\boldsymbol{P}$. vaginatum. Botanical Gazette, v.144, p.433-438, 1983.

QUARÍN, C.L. et al. Cytology and reproductive behavior of diploid, tetraploid and hexaploid germplasm accessions of a wild forage grass: Paspalum compressifolium. Euphytica, v.90, p.345-349, 1996. Available from: <http://dx.doi.org/10.1007/BF00027486> Accessed: dec. 12, 2012. doi: 10.1007/BF00027486.

ROSENGURTT, B. et al. Gramíneas Uruguayas. Montevideo: Universidad de la República, Departamento de Publicaciones, 1970. 492p.

SIENA, L.A. et al. Genetic and embryological evidences of apomixis at the diploid level in Paspalum rufum support recurrent auto-polyploidization in the species. Sexual Plant Reproduction, v.21, p.205-215, 2008. Available from: <http://link.springer.com/ article/10.1007/s00497-008-0080-1>. Accessed: dec. 13, 2012. doi: 10.1007/s00497-008-0080-1.

VALLS, J.F.M. Recursos genéticos de espécies de Paspalum no Brasil. In: ENCONTRO INTERNACIONAL SOBRE MELHORAMENTO GENÉTICO DE PASPALUM, 1987, Nova Odessa, Brasil. Anais... Nova Odessa: Instituto de Zootecnia, 1987. p.3-13.

VALLS, J.F.M.; POZZOBON, M.T. Variação apresentada pelos principais grupos taxonômicos de Paspalum com interesse forrageiro no Brasil. In: ENCONTRO INTERNACIONAL SOBRE MELHORAMENTO GENÉTICO DE PASPALUM, 1987, Nova Odessa, Brasil. Anais... Nova Odessa: Instituto de Zootecnia, 1987. p.15-21.

ZULOAGA, F.O. et al. Systematics of Paspalum Group Notata (Poaceae-Panicoideae-Paniceae). Systematic Botany Monographs, v.71, p.1-74, 2004. 